\title{
CHARACTERIZATION OF PORTUGUESE DIATOMITES IN ORDER TO ASSESS POTENTIAL APPLICATIONS
}

\author{
CRISTIANA COSTA ${ }^{1) *}$, ANA VELOSA ${ }^{2)}$, ÂNGELA CERQUEIRA ${ }^{1)}$, \\ PAULO CAETANO ${ }^{3)}$ and FERNANDO ROCHA ${ }^{1)}$
}

\author{
1) GeoBioTec, Geosciences Department, University of Aveiro, Aveiro, Portugal \\ ${ }^{2)}$ RISCO, Civil Engineering Department, University of Aveiro, Aveiro, Portugal \\ 3) GeoBioTec, Earth Science Department, Faculty of Science and Technology/UNL, Lisbon, Portugal \\ *Corresponding author's e-mail: cristianacosta@ua.pt
}

\section{ARTICLE INFO}

Article history:

Received 25 September 2017

Accepted 8 March 2018

Available online 20 March 2018

Keywords:

Diatomite

Characterization

Beneficiation

Applications

\begin{abstract}
Diatomite is a siliceous sedimentary rock, and it can be used in many industrial applications due to its high porosity, low density porous and permeable structure, chemical resistance, high purity, high specific surface area, absorptive capacity and to its absorbent properties. The best known Portuguese occurrences of diatomite are located in the regions of Óbidos and Rio Maior. The purpose of this research is to characterize the Rio Maior and Amieira diatomite and beneficiate this rock to be used in some potential applications locally or not. The studied diatomites present a fine texture; chemically the samples have a high $\mathrm{SiO}_{2}$ content, the principal minerlas are quartz and amorphous opal. The studied diatomites benefited with temperature and addition of $\mathrm{NaCl}$ (acting as accelerator of the crystallization process), with $5 \%$ of $\mathrm{NaCl}$ being reduced the transformation temperature of the amorphous opal in opal C / CT at about $200{ }^{\circ} \mathrm{C}$.

The diatomites from Rio Maior and Amieira in natural state has an enormous potential as absorbent, of heavy metals (e.g. in soil contamination) or dyes (textile industry).

These diatomites after beneficiation can be used in construction materials (as additive), being more reactive and crystalline than in the natural state, diatomites can be promoters of mechanical resistance in mortars and geopolymers.
\end{abstract}

\section{INTRODUCTION}

Diatomite is a siliceous sedimentary rock, also called "diatomaceous earth", composed by more than $50 \%$ of diatoms shells (Velho, 1998).

Diatoms are algae of fresh, brackish or salt water, having a silica rich shell which is composed by natural opal $\mathrm{C}$ or opal $\mathrm{C} / \mathrm{T}$ and cristobalite $\alpha$.

In terms of chemical composition, diatomite rocks are constituted essentially by silica, usually between 80 to $90 \%$.

Diatomite may contain impurities due to the presence of iron, aluminum, magnesium and calcium. In mineralogical terms, clay minerals, quartz, gypsum, calcite, feldspars, micas, and, less frequently, salts, phosphates, pyrite, chert and volcanic ash, may appear as accessory minerals.

Diatomaceous earth and its impurities are usually separated using air separators, cyclones or mechanical mixing and magnetic separators. However, the diatomaceous earth is normally handled by calcination or flux calcination methods in order to benefit diatomaceous earth for its filtration capacities. The aluminum oxide present in the clayey fraction can clog the voids of the particles of the diatomite decreasing filtration capacities. Usually, the calcination of natural diatomite is done in a rotary kiln at $870-1100{ }^{\circ} \mathrm{C}$.

Diatomaceous earth is used in many industrial applications due to its high porosity, low density porous and permeable structure, chemical resistance, high purity, high specific surface area, absorptive capacity and to its absorbent properties (Ediz et al., 2010). It's most common industrial use is for filtration of sugar syrup, beer, whiskey, wine, fruit juices, water, vegetable or mineral oils and pharmaceuticals. Diatomite has been used as pozzolanic additive for Portland cement, mortars and grouts. Diatomite is characterized as a natural pozzolan satisfying the standard TS EN 197-1 in terms of the active silica content (Xu et al., 2014). Opal-A (amorphous silica) can react with $\mathrm{Ca}(\mathrm{OH})_{2}$ to produce hydrated calcium silicate. Diatomite is relatively abundant and accessible resource, requiring simple manufacturing technique, low energy consumption and having low impact on environment (Degirmenci et al., 2009).

The purpose of this research is to characterize the Rio Maior and Amieira diatomite and beneficiate this rock to be used in some potential applications locally or not. 


\section{MATERIALS AND METHODS}

\subsection{SAMPLING}

The best known Portuguese occurrences of diatomite are located in the regions of Obidos and Rio Maior (Fig. 1). In these areas the diatomite deposits have been intensively exploited, usually in association with lignite. Close to Lisbon, South of Tagus river, there are other smaller occurrences of diatomite, especially in Sesimbra region.

For this study, samples were collected from Rio Maior and Sesimbra deposits.

\subsubsection{RIO MAIOR (RM)}

In Rio Maior, the diatomite was explored in Espadanal mine, located in an industrial area (Fig. 2).

The deposit of Espadanal consists essentially a succession of sub-horizontal layers of Pliocene diatomites and lignites, deposited into a small shallow depression excavated in the Miocene continental substrate.

The group suffered a little synclinal deformation, North-South axis, with one edge lifted to the west, where the lignite outcrops. The thickness of the lignite is greater in the center of the basin where achieves seven meters, reducing quickly to the edges of the syncline. The diatomaceous earth was exploited at several points and reaches in the central part of the deposit, a thickness close to sixty meters (Brandão et al., 2006).

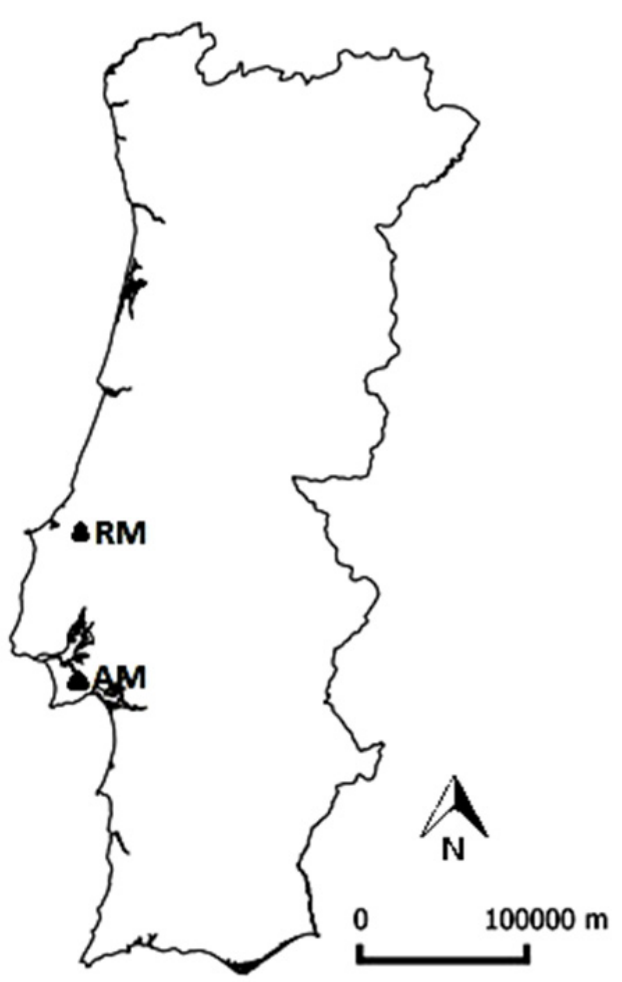

Fig. 1 Collected symplex RM - Rio Maior and AM - Amieira.
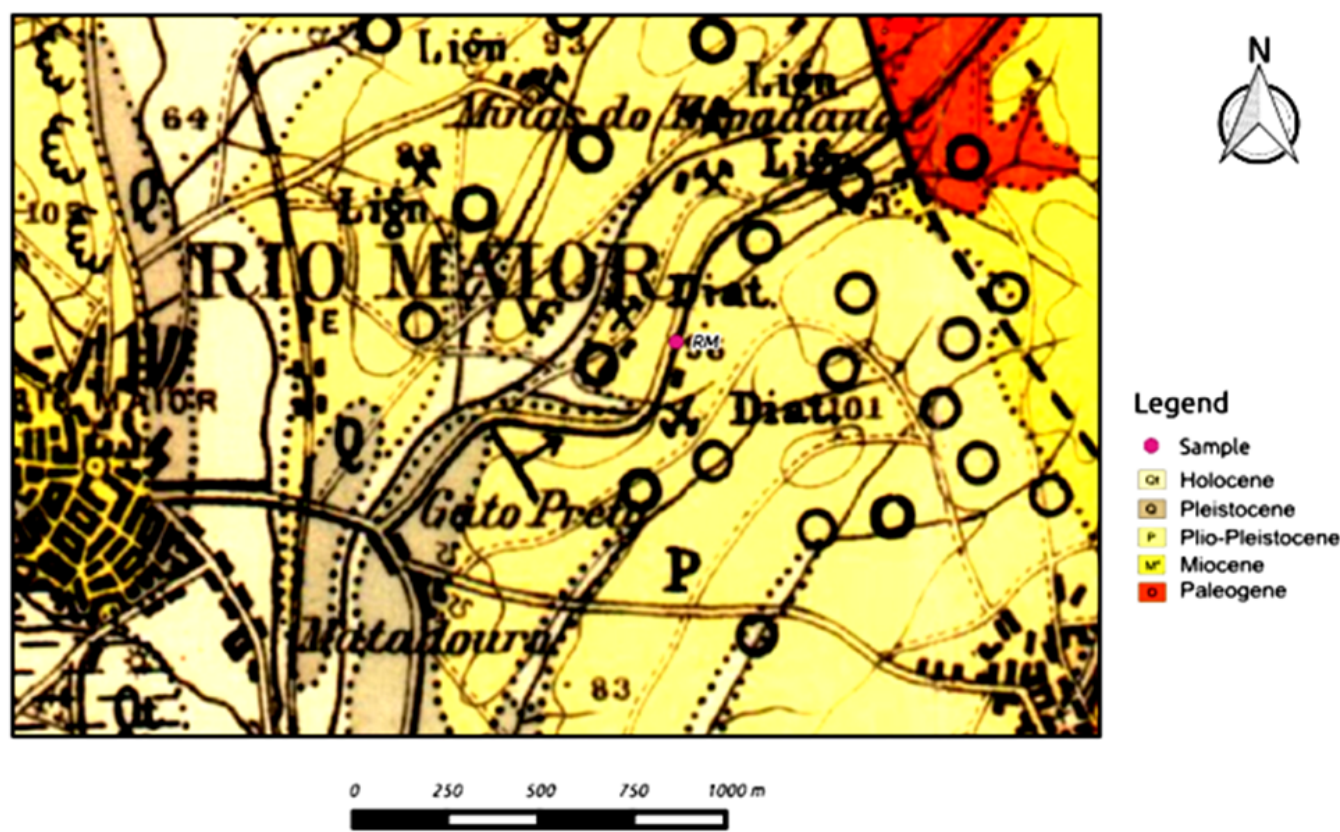

Fig. 2 Rio Maior sampling (adapted from Geological Map of Portugal, scale 1:50000, sheet 26D). 


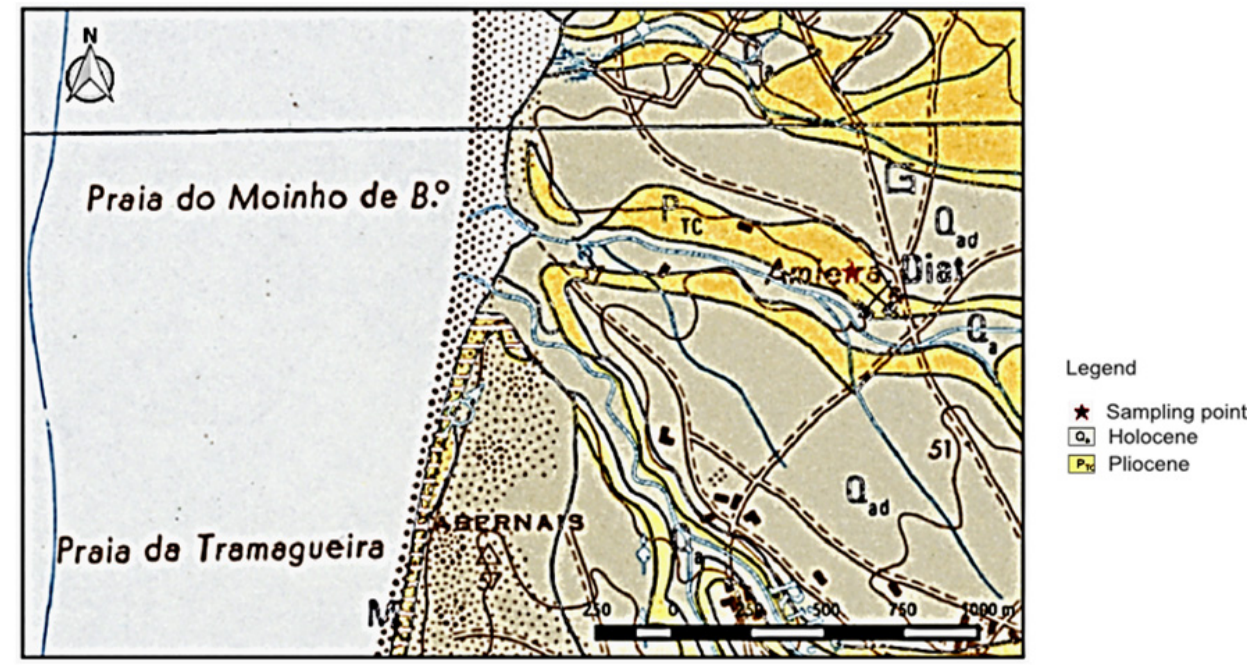

Fig. 3 Amieira sampling (adapted from Geological Map of Portugal, scale 1:50000, sheet 38B).

\subsubsection{AMIEIRA - SESIMBRA (AM)}

Diatomite deposits of the Setubal Peninsula region (Fig. 3) are intercalated in the top of the unit " $\mathrm{P}_{3} \mathrm{Q}$ - upper complex of fine sand, calibrated, with conglomeratic intercalations, diatomites and lignites" from Plio-Plistocene age, labeled in geological maps as unit "P $\mathrm{P}_{\mathrm{SM}}$ - Santa Marta Formation". The depositional environment seems to correspond to fluvial-lacustrine underwater sedimentation (Caetano et al., 2006).

The deposit of diatomaceous earth that was more intensely explored among all the Sesimbra region is located in Amieira, around $1 \mathrm{~km}$ NNE of Alfarim (Fig. 3); the exploration is labeled on geological map of Setubal as "suspended or abandoned mining".

The deposit is small, with a maximum of 3 meters thick. The diatomaceous earth shows a whitish color and has intercalated sandy beds (Caetano et al., 2006).

\subsection{METHODS}

An X-ray grain size analyzer (Micromeritics ${ }^{\circledR}$ Sedigraph 5100) was used for the assessment of grain size distribution bellow $63 \mu \mathrm{m}$ (obtained by wet sieving).

The chemical composition of diatomite samples was assessed by X-ray fluorescence (XRF) using an XRF-Panalytical AXIOS PW4400/40. Loss-onIgnition (LOI) was determined by heating $1 \mathrm{~g}$ of the sample at $1.000{ }^{\circ} \mathrm{C}$ for $1 \mathrm{~h}$ in furnace Cassel, model MF20, series 83215.

Qualitative and semi-quantitative mineralogical analyses were carried out by X-ray diffraction (XRD) using a Philips ${ }^{\circledR} /$ Panalytical X'Pert-Pro MPD, $\mathrm{Cu} \mathrm{Ka}$ $(\lambda=1,5405 \AA)$ radiation, with $0.02^{\circ} 2 \theta \mathrm{s}^{-1}$ steps in goniometer speed. The identification of the different mineral phases followed the criteria recommended by Brindley and Brown (1980), the Joint Committee for Powder Diffraction Standards, and Mellinger (1979).
Specific Surface Area (SSA) was determined by BET method (Brunauer et al., 1938) using a Micromeritics Gemini V2.0.

Differential thermal analysis/thermogravimetry (DTA/TG) were carried out to establish the optimum range of calcination temperature for diatomite. The apparatus used was a SETARAM-SETSYS evolution S60-58292 and the heating rate was $10^{\circ} \mathrm{C} / \mathrm{min}$ under argon atmosphere $(3 \mathrm{l} / \mathrm{h})$ between $\approx 20^{\circ} \mathrm{C}$ and $1000^{\circ} \mathrm{C}$.

The microstructural characterization was carried out by scanning electron microscopy (SEM - Hitachi, SU 70) and energy dispersive X-ray spectrometry (EDS - EDAX with detector Bruker AXS, software: Quantax) operated at 3-30 kV.

The specific surface area analysis was accomplished in Micromeritics Gemini 2.0 equipment according to the BET method (Brunauer et al., 1938).

The diatomite was thermally treated in a programmable laboratory furnace. It was heated from ambient to $1000{ }^{\circ} \mathrm{C}$ and $1200{ }^{\circ} \mathrm{C}$, and was kept at the selected temperature for 4 hours. The diatomaceous earth was thermally and chemically treated using $\mathrm{NaCl}$ in two different percentages, $5 \%$ and $10 \%$ (w/w), and being heated to $1000{ }^{\circ} \mathrm{C}$ for 4 hours. The $\mathrm{NaCl}$ is used as a white flux to promote the change stage of amorphous opal (Ediz et al., 2010).

\section{RESULTS AND DISCUSSION \\ 3.1. GRANULOMETRIC ANALYSIS}

Both studied raw diatomites are very fine, composed only by very fine sand and silt/caly fractions, with $100 \%$ particles $<100 \mu \mathrm{m}$. Table 1 presents the grain size analysis (sedigraph) of raw diatomites used in this study.

Results emphasizes that both diatomites are very fine (practically clayey), Rio Maior (RM) being slightly finer. 
Table 1 Grain size analysis of the fraction $100 \mu \mathrm{m}$ to $0.20 \mu \mathrm{m}$ (sedigraph).

\begin{tabular}{cccc}
\hline sample & number of cycles & median & modal \\
\hline RM & 181 & $0.74 \mu \mathrm{m}$ & $0.50 \mu \mathrm{m}$ \\
AM & 172 & $2.44 \mu \mathrm{m}$ & $1.18 \mu \mathrm{m}$ \\
\hline
\end{tabular}

Table 2 Chemical analysis of diatomite samples using XRF.

\begin{tabular}{cllllllllllllrr}
\hline $\mathbf{( \% )}$ & $\mathbf{N a}_{\mathbf{2}} \mathbf{O}$ & $\mathbf{M g O}$ & $\mathbf{A l}_{\mathbf{2}} \mathbf{O}_{\mathbf{3}}$ & $\mathbf{S i O}_{\mathbf{2}}$ & $\mathbf{P}_{\mathbf{2}} \mathbf{O}_{\mathbf{5}}$ & $\mathbf{S O}_{\mathbf{3}}$ & $\mathbf{C l}$ & $\mathbf{K}_{\mathbf{2}} \mathbf{O}$ & $\mathbf{C a O}$ & $\mathbf{T i O}_{2}$ & $\mathbf{F e}_{2} \mathbf{O}_{3}$ & $\mathbf{Z r}$ & $\mathbf{M n O}$ & $\mathbf{L O I} *$ \\
\hline $\mathbf{R M}$ & 0.12 & 0.26 & 8.04 & 82.99 & 0.02 & 0.03 & 0.04 & 0.58 & 0.03 & 0.35 & 1.80 & 0.01 & - & 5.71 \\
$\mathbf{A M}$ & 0.14 & 0.27 & 6.37 & 85.86 & 0.01 & 0.04 & 0.03 & 0.95 & 0.04 & 0.25 & 1.02 & - & 0.01 & 4.96 \\
\hline Hungary*1 & 0.12 & 1.98 & 4.14 & 77.68 & - & - & - & 0.39 & 1.09 & - & 3.23 & - & - & 11.23 \\
Romania*1 & 0.5 & 1.98 & 9.8 & 75 & - & - & - & 1.34 & 0.7 & - & 3.85 & - & - & 6.91 \\
\hline
\end{tabular}

*LOI: lost-on-ignition, *1: Diatomites referenced in Stamatakis et al. (2003)

\subsection{CHEMICAL ANALYSIS}

Table 2 presents the chemical analysis of raw diatomites used in this study. The chemical results show that the diatomite from Amieira (AM) has higher silica $\left(\mathrm{SiO}_{2}\right)$ content, and less aluminum $\left(\mathrm{Al}_{2} \mathrm{O}_{3}\right)$ and iron $\left(\mathrm{Fe}_{2} \mathrm{O}_{3}\right)$ contents, meaning that this sample is purer than RM sample. These results are in accordance with those of typical diatomite, in which usually show silica content ranging from 80 to $90 \%$ (Ediz et al., 2010).

Comparing the results with two different diatomites from Hungary and Romania (Stamatakis et al., 2003) it's verified that there aren`t a big differences, but the $\mathrm{SiO}_{2}$ percentage is a quite higher in our samples meaning that these samples are more pure. In this case, it is important because the final application of the diatomite will be like an additive in construction materials.

\subsection{MINERALOGICAL ANALYSIS}

XRD peaks of the raw and beneficiated diatomites are shown in Figures 4 and 5. The samples are composed essentially by quartz and opal-A; feldspars and phyllosilicates are present too, in minor quantity. Considering the mineralogical composition of referenced samples from Hungary and Romania, the results are similar, it is not found significate differences (Stamatakis et al., 2003). XRD diagrams show extensive amorphous opal structures, in evident broad band between $19^{\circ}$ and $28^{\circ} 2 \theta$, in both raw diatomite and diatomite heated without additive $(\mathrm{NaCl})$. Generally, the amorphous structure is lost after calcination plus $\mathrm{NaCl}$ addition, and opal $\mathrm{C} / \mathrm{CT}$ peak appears close to $21.5^{\circ} 2 \theta$. The amorphous phase is totally lost in sample AM, but in sample RM there is some amorphous phase evidence even after treatment. The fact that sample AM is purer $(\sim 86 \%$ $\mathrm{SiO}_{2}$ ) justifies the transformation, of the amorphous

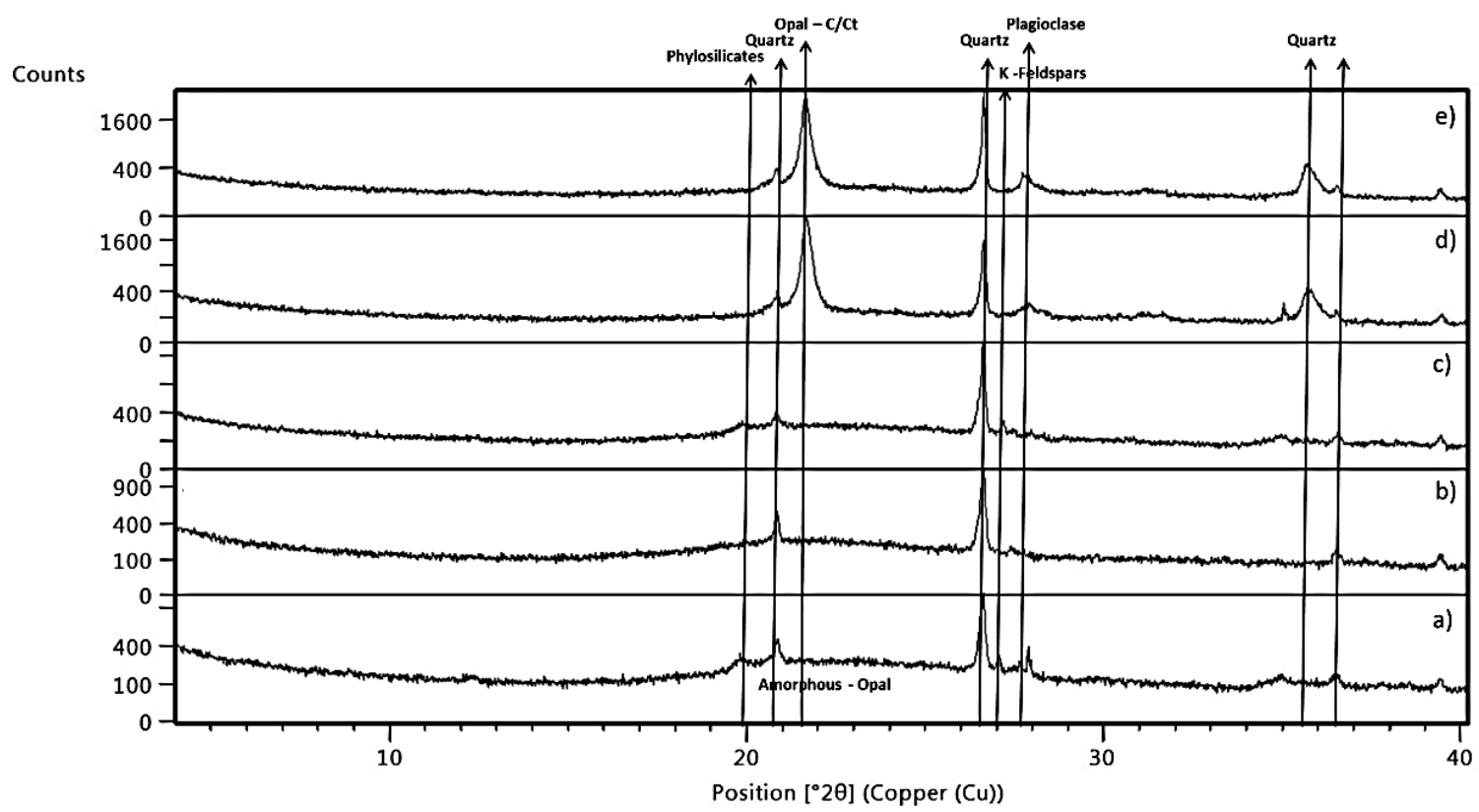

Fig. 4 XRD of AM sample: a) AM raw material, b) AM $1000{ }^{\circ} \mathrm{C}$, c) AM $1200{ }^{\circ} \mathrm{C}$, d) AM $1000{ }^{\circ} \mathrm{C}+\mathrm{NaCl}$ $(5 \%)$, e) $\mathrm{AM} 1000^{\circ} \mathrm{C}+\mathrm{NaCl}(10 \%)$. 


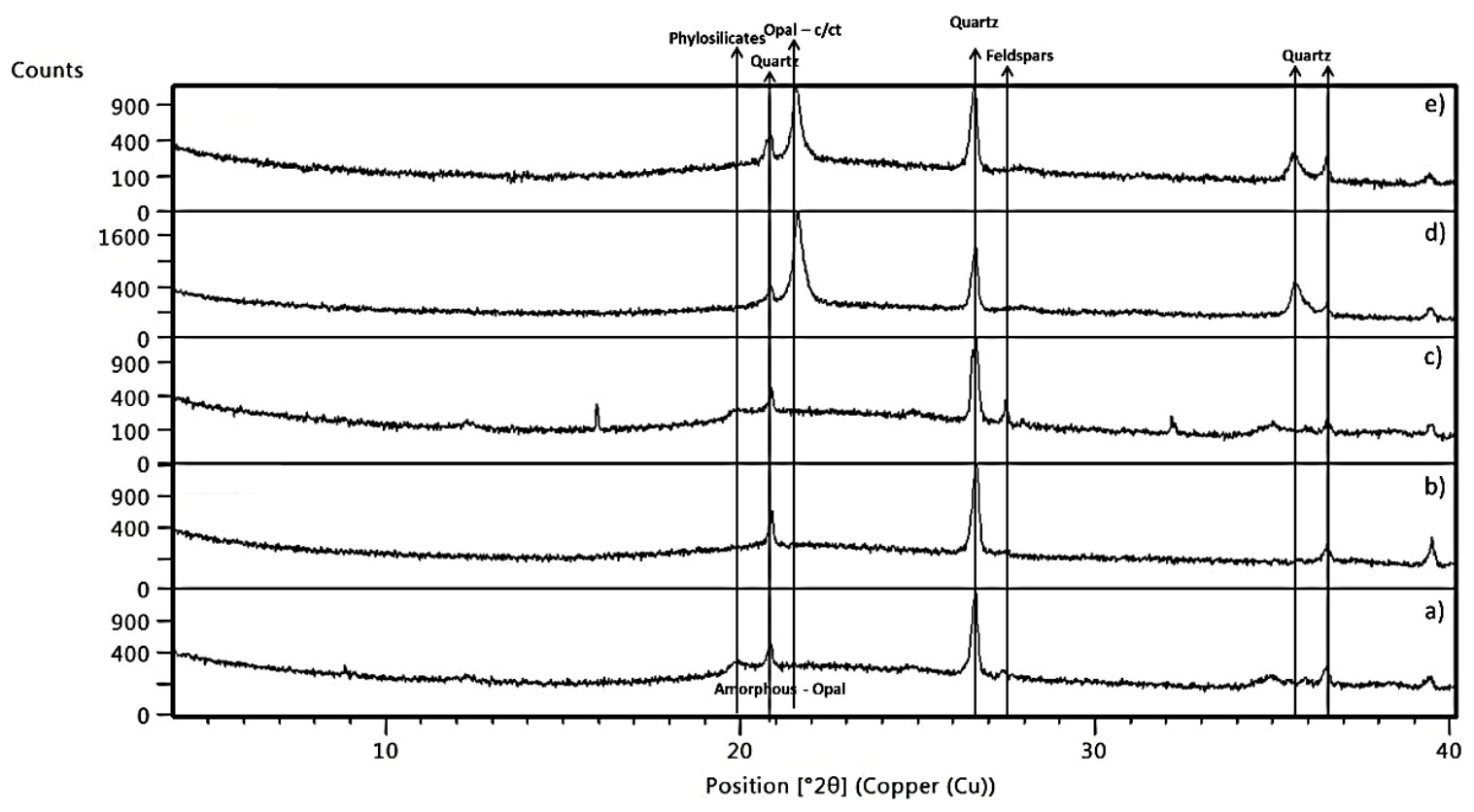

Fig. 5 XRD of RM sample: a) RM raw material, b) $\mathrm{RM} 100{ }^{\circ} \mathrm{C}$, c) $\mathrm{RM} 1200{ }^{\circ} \mathrm{C}$, d) $\mathrm{RM} 1000{ }^{\circ} \mathrm{C}+$ $\mathrm{NaCl}(5 \%)$, e) $\mathrm{RM} 1000{ }^{\circ} \mathrm{C}+\mathrm{NaCl}(10 \%)$.

opal in to opal $\mathrm{C} / \mathrm{CT}$ at less temperature. There is a clear crystallization after the beneficiation with heating and $\mathrm{NaCl}$ addition. After just calcination, there is a small enhancing of structural order in the two different samples (AM and RM). On the other hand, $5 \%$ of $\mathrm{NaCl}$ is enough to have a crystallization process, with no significant better results when increasing to $10 \%$ of $\mathrm{NaCl} . \mathrm{NaCl}$ supports the formation of agglomerated diatomite particles (Martinovic et al., 2006). The alkaline activation process (with $\mathrm{NaCl}$ ), demolished the amorphous opal structure. This process provides the liberation of silica, and with the temperature during the calcination the crystallization process is accelerated $(\mathrm{NaCl}$ acts as flux) and the opal C/CT is formed (Ediz et al., 2010).

\subsection{THERMAL ANALYSIS}

The thermal behavior of diatomite samples in terms of DTA/TG is shown in Figures 6 and 7. Both samples AM and RM have a similar thermal behavior, showing no significant differences between them. From the DTA curves, the surface and hygroscopic water removal reveal an endothermic peak in the heating stage (between $24{ }^{\circ} \mathrm{C}$ to $400{ }^{\circ} \mathrm{C}$ ). From the TG curve, it is seen that diatomite lost $7.46 \%$ in AM sample and $6.79 \%$ in RM sample of their surface humidity at $200{ }^{\circ} \mathrm{C}$. With the increase of temperature, weight lost continued up to $1000{ }^{\circ} \mathrm{C}$ and $12.07 \%$ weight loss occurred owing to the degradation of phyllosilicates and amorphous opal. After this period, a weight loss of $0.163 \%$ in AM sample and $0.256 \%$

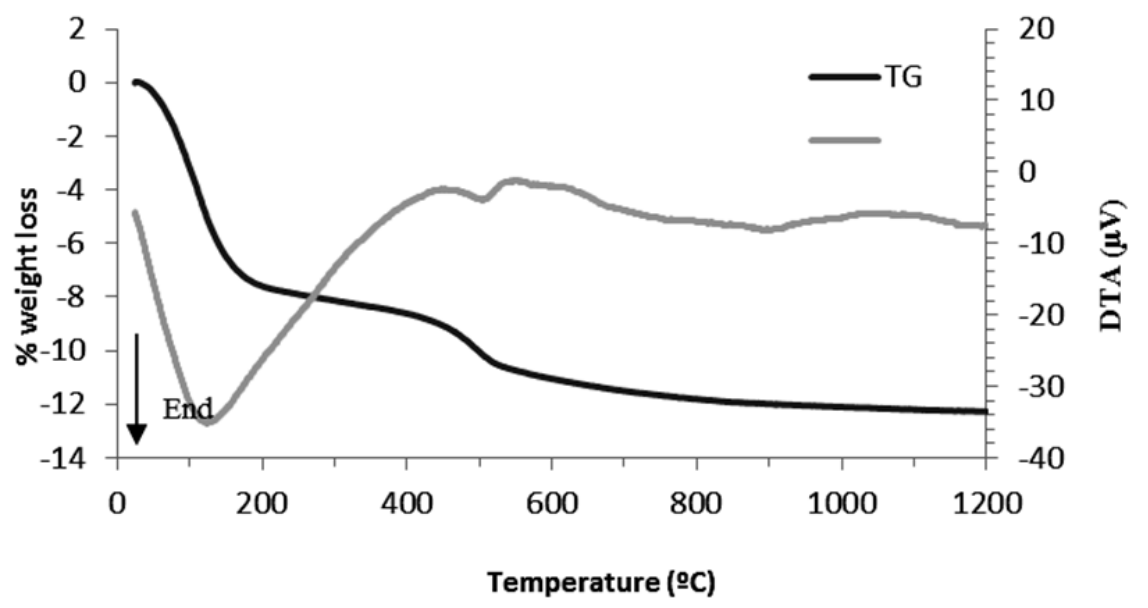

Fig. 6 DTA/TG results of AM sample (*End - endothermic). 


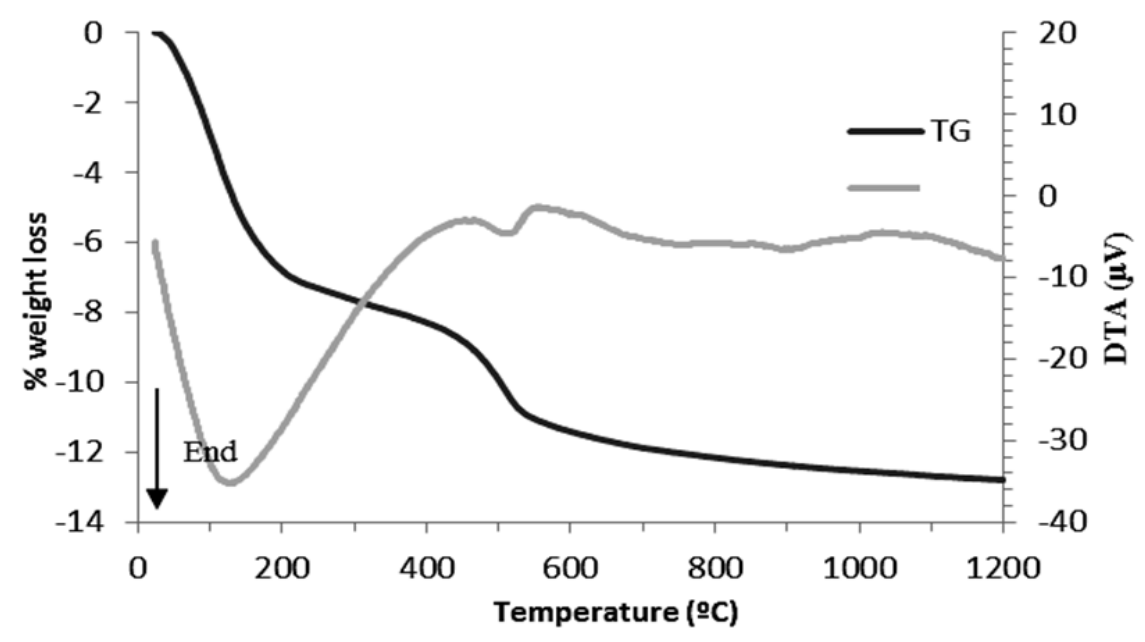

Fig. 7 DTA/TG results of RM sample (*End - endothermic).

in RM sample were observed through the appearance of crystoballite which proved the establishment of stronger crystal bonds.

Figures 8 and 9 represent the results of the of DTA/TG results of AM and RM samples calcined with $5 \% \mathrm{NaCl}$. Through the analysis of the graphs, there are no endothermic or exothermic peaks, verifying that the samples after this treatment were practically inert. The apparent initial exothermic peak of the RM sample is due to the fact that the apparatus where the test was performed is not very sensitive to low temperatures. Through the TG analysis, a small gain of mass in the two samples is observed, which seems to be more accentuated due to the scale of the graph, which is explained by the incorporation of possible particles present in the atmosphere of the chamber where the test was performed. The results obtained from the thermal analysis confirm the XRD results, showing that the amorphous opal is all transformed and crystallized with heating at $1000{ }^{\circ} \mathrm{C}$ and with $5 \% \mathrm{NaCl}$, giving the required inertization of the materials analyzed. If there is amorphous opal in this phase, in the results of DTA/TG the material still would not be virtually inert. In this case, the absence of endothermic and exothermic peaks confirms the total crystallization of calcined material to $1000{ }^{\circ} \mathrm{C}$ with $5 \% \mathrm{NaCl}$. These results are confirmed again by microstructural and specific surface area analyzes. Through the microstructural analysis it is verified that there is a decrease of the porosity of the samples, according the decrease of specific surface area of the samples calcined with $5 \%$ of $\mathrm{NaCl}$.

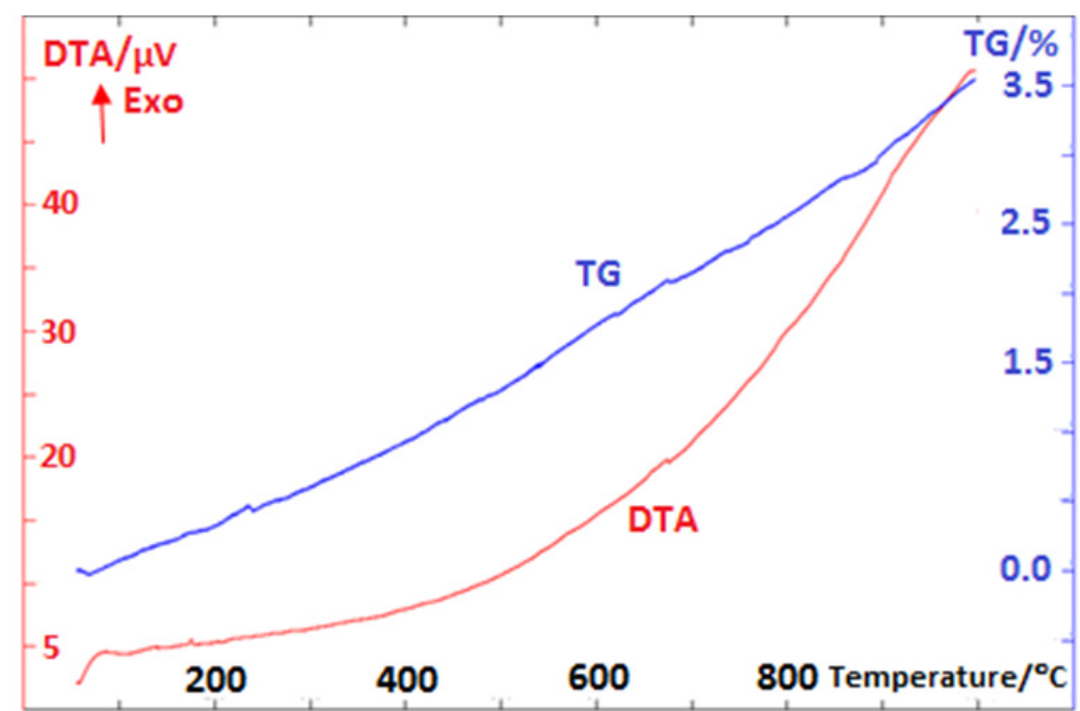

Fig. 8 DTA/TG results of AM sample with $\mathrm{NaCl}(5 \%)$. 


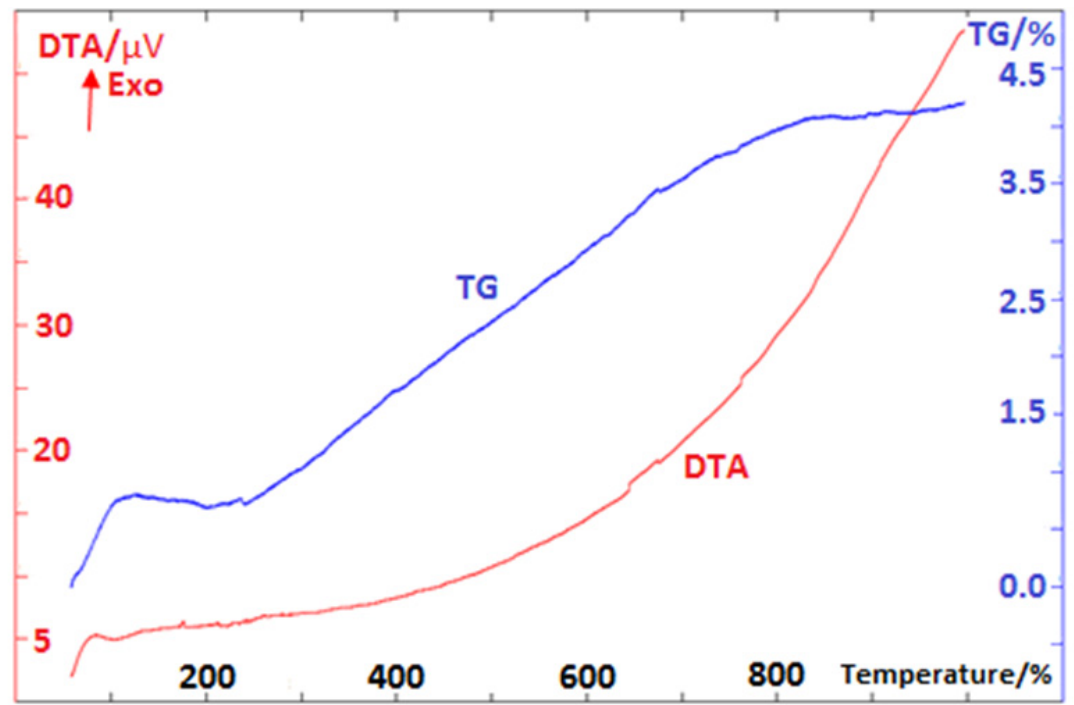

Fig. 9 DTA/TG results of $\mathrm{RM}$ sample with $\mathrm{NaCl}(5 \%)$.
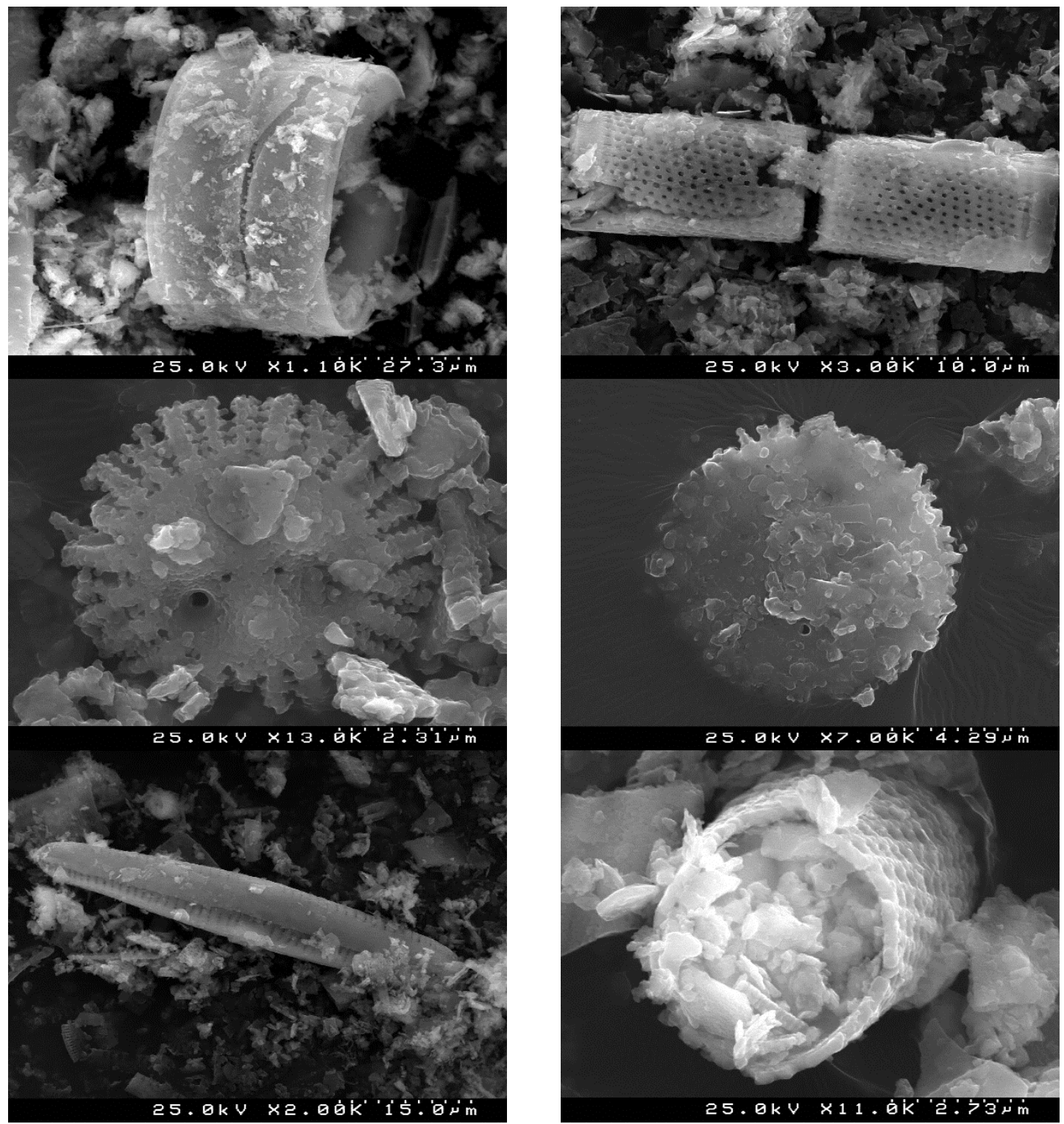

Fig. 10 Different diatom species observed through SEM in RM (left side) and AM (right side) samples (the scale bar are in right and inferior side of the images). 


\subsection{MICROSTRUCTURAL ANALYSIS}

Microscopic observations have been studied to identify the existence of diatom and the porous microstructure before and after beneficiation (as describe in chapter 3.3). Elliptical and elongated frustules are common, different species can be observed (Fig. 10). In order to compare the microstructure of samples with and without treatments, SEM images are shown in Figure 11. It is possible to see differences between the raw diatomite
(Fig. 11a) and the diatomite heated at $1200{ }^{\circ} \mathrm{C}$ (Fig. 11b), the latter being more homogeneous and less porous, for the two different samples analyzed (AM and RM). After calcination and with an addition of $5 \%$ of $\mathrm{NaCl}$ (Fig. 11c) the structure is clearly more crystalline.

\subsection{SPECIFIC SURFACE AREA ANAL YSIS}

The Specific Surface Area (SSA) of diatomite samples, before and after calcination, is shown in
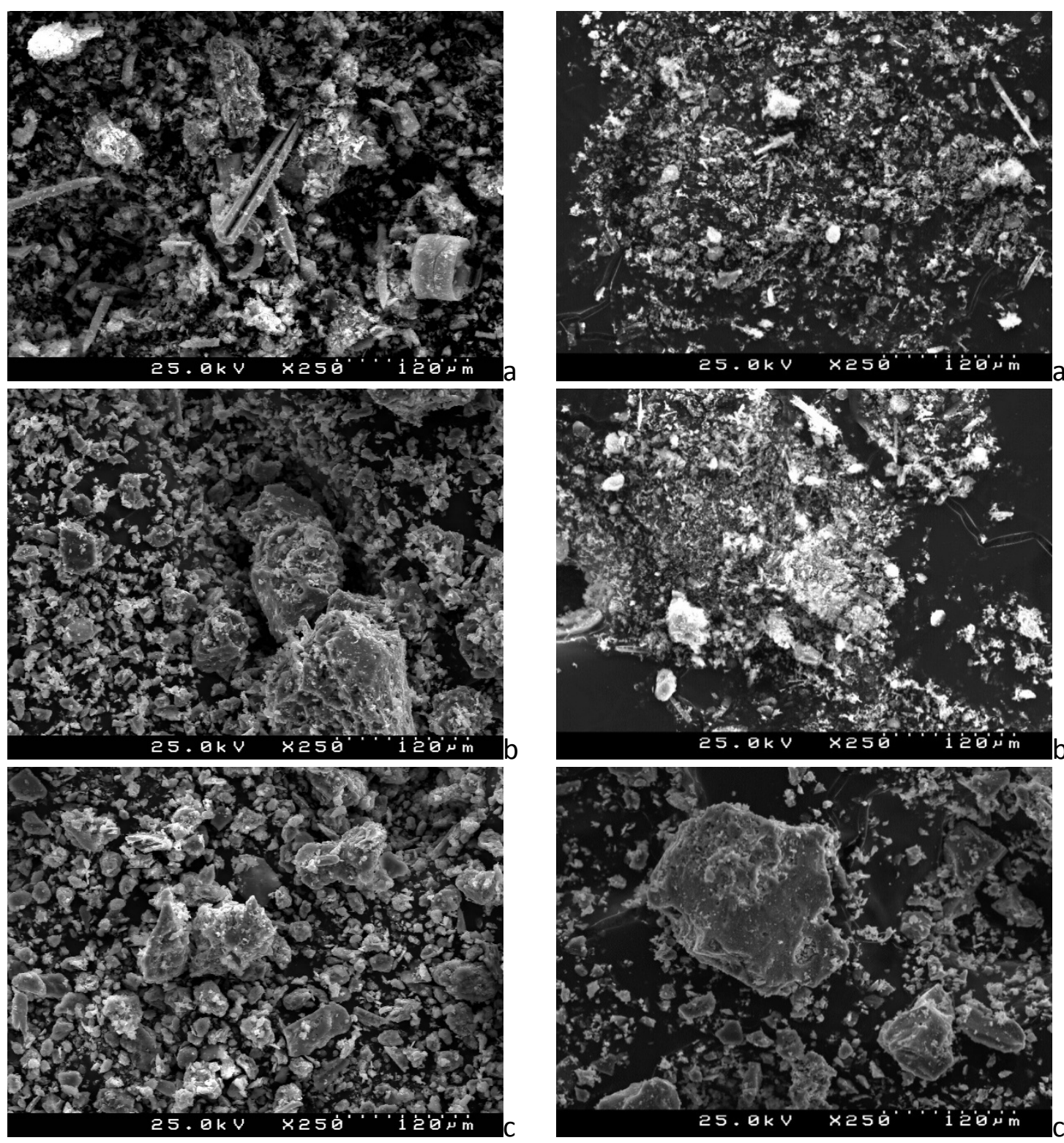

Fig. 11 SEM images of sample RM (left side) and AM (right side): a) raw material b) $1200{ }^{\circ} \mathrm{C}$ c) $1000{ }^{\circ} \mathrm{C}+5 \% \mathrm{NaCl}$ (the scale bar are in right and inferior side of the images). 
Table 3 SSA of diatomite samples using BET $\left(\mathrm{m}^{2} / \mathrm{g}\right)$.

\begin{tabular}{cccc}
\hline sample & raw & heated $\left(1200^{\circ} \mathrm{C}\right)$ & calcined with $5 \% \mathrm{NaCl}$ \\
\hline RM & 18.9 & 2.3 & 0.01 \\
AM & 16.4 & 5.9 & 1.90 \\
\hline
\end{tabular}

Table 3. Only values of the calcined samples with $5 \%$ $\mathrm{NaCl}$ were added, because with this amount we already have total transformation of the amorphous opal, and it was not necessary to make the samples calcined with $10 \% \mathrm{NaCl}$.

It is possible to see clear differences between the raw diatomite, the diatomite heated at $1200{ }^{\circ} \mathrm{C}$ and the diatomite calcined at $1000^{\circ} \mathrm{C}$ with $5 \%$ of $\mathrm{NaCl}$. With the heating the specific surface area decrease because the structure are more compacted. The samples calcined with $5 \%$ of $\mathrm{NaCl}$ shows that almost amorphous opals are transforming in opal C/CT. This behaviour is confirmed with the sharp decrease of specific surface area.

\section{POSSIBLE APPLICATIONS OF DIATOMITE}

Diatomite is a very porous rock with a fine particle size and a low specific gravity. The properties of studied diatomites like grain size, porosity, density, chemical and mineralogical composition allow these materials capacity have a wide application in different industries. For example, according to Maina et al. (2011), diatomite can be used to increase lime reactivity towards $\mathrm{SO}_{2}$ abatement. These properties make it useful as a filter media, an absorbent, and as a lightweight filler for rubber, paint, and plastics.

The diatomite can have an important role in the environment, due to the high porosity and low density the diatomite can be an excellent heavy metals absorbent. According to Irani et al. (2011) the diatomite is a good lead absorbent and it is better than dolomite or perlite. Actually, diatomite has a very small particle size, a high porosity, and is relatively inert. That makes it an excellent material for use as a filter.

The studied diatomites present a fine granulometry; in terms of chemical composition the samples has a high $\mathrm{SiO}_{2}$ content (exceeding $82 \%$ ), mineralogically present in particular quartz and amorphous opal, and in smaller amounts feldspars and phyllosilicates. Thermal analysis shows that these two materials at about $1000{ }^{\circ} \mathrm{C}$ the crystallization of amorphous opal. After the improvement of these materials with temperature and addition of $\mathrm{NaCl}$ (functioning as a flux), the samples become more crystalline with the transformation of amorphous opal to opal $\mathrm{C} / \mathrm{CT}$.

The diatomites from Rio Maior and Amieira in natural state has an enormous potential as absorbent, of heavy metals (e.g. in soil contamination) or dyes (textile industry).
These diatomites after beneficiation can be used in construction materials (as additive), being more reactive and crystalline than in the natural state, diatomites can be promoters of mechanical resistance in mortars and geopolymers.

In futures studies, the diatomites studied in this paper will be tested in soils with a significate concentration of heavy metals to test the absorptive capacity. The adsorption of some textile dyes by diatomite was investigated by Erdem et al. (2005) with success. This can be another application of Portuguese diatomites because the presence of color in many industrial effluent streams is aesthetically undesirable. This application can be used in two different fields (environmental and construction materials), because dyed diatomite could be used for the production of colored and blended cements increasing the strength.

\section{CONCLUSIONS}

Studied diatomite rocks are light in weight and rich in soft materials as well as in amorphous silica, which is mainly present in the form of diatom frustules.

The diatomite of Rio Maior and Amieira presents similar characteristics, emphasizing the fact that the diatomite of Amieiria is purer (presented more $\mathrm{SiO}_{2}$ content), and Rio Maior diatomite presents a finer texture.

The process of beneficiation shows that is not necessary $10 \%$ of $\mathrm{NaCl}, 5 \%$ being enough to have a crystallization process. On the other hand, it was clear that just calcination is not sufficient to generate opal C/CT.

The characterization results shows that both Portuguese diatomites are good; however, depending of the final application, it's important to note that Rio Maior diatomites have finer grain size although the specific surface area it's similar for both

The diatomite can be used in a large range of applications, and the diatomite from Rio Maior and Amieira have a good properties when compared with others already studied and/or being used. Thus, these diatomites have a potential as absorvents of dyes or heavy metals, or as additive in construction materials, locally or wide-broader.

This study is important to know the main characteristics of both diatomites and choose the adequate beneficiation procedures for different applications. With the treatment and reduction of the amorphous material for application in civil 
construction, serving with a possible source of alternative silica, increasing the resistance of the material. On the other hand, without any treatment the diatomite can be used as absorbent in different industries.

\section{ACKNOWLEDGEMENTS}

The first author benefited a $\mathrm{PhD}$ scholarship (SFRH/BD/102837/2014) financed by Fundação para a Ciência e Tecnologia (FCT), Portugal. This work was partially supported by Geobiotec Research Centre (UID/GEO/04035/2013) and funded by FEDER funds through the Operational Program Competitiveness Factors e COMPETE and by National funds through FCT.

\section{REFERENCES}

Brandão, J.M. and Rocha, N.A.: 2006, Espadanal mines briquettes factory (Rio Maior, Portugal). Modernidade esquecida. De Re Metallica, 6-7, 13-22, (in Portugal).

Brunauer, S., Emmett, P.H. and Teller, E.J.: 1938, Adsorption of gases on multimolecular layers. J. Am. Chem. Soc., 60, 309-319.

Caetano, P.S. and Rodrigues, P.: 2006, The diatomite mine at Amieira (Sesimbra): an interesting example of geological-mining heritage. VII Congresso Nacional de Geologia (Estremoz), (in Portugal).

Ediz, N., Bentli, I. and Tatar, I.: 2010, Improvement in filtration characteristics of diatomite by calcination. International Journal of Mineral Processing, 94, 129134. DOI: $10.1016 /$ j.minpro.2010.02.004

Erdem, E., Çolgeçen, G. and Donat, R.: 2005, The removal of textile dyes by diatomite earth. Journal of Colloid and Interface Science, 282, 314-319.

Irani, M., Amjadi, M. and Mousavian, M.A.: 2011, Comparative study of lead sorption onto natural perlite, dolomite and diatomite. Chemical Engineering Journal, 178, 317-323.

Loganina, V.I., Simonov, E.E., Jezierski, W. and Malaszkiewicz, D.: 2014, Application of activated diatomite for dry lime mixes. Construction and Building Materials, 65, 29-37.

DOI: 10.1016/j.conbuildmat.2014.04.098
Maina, P. and Mbarawa, M.: 2011, Enhancement of lime reactivity by addition of diatomite. Fuel Processing Technology, 92, 1910-1919.

Manuppella, G., Pais, P., Legoinha, P. and Rey, J.: 1994, Carta Geológica de Portugal, na escala de 1:50.000. Folha 38-B, (Setúbal).

Martinovic, S., Vlahovic, M., Boljanac, T. and Pavlovi, L.: 2006, Preparation of filter aids based on diatomites. Int. J. Miner. Process., 80, 255-260, 006. DOI: $10.1016 /$ j.minpro.2006.05.006

San, O., Gören, R. and Özgür, C.: 2009, Purification of diatomite powder by acid leaching for use in fabrication of porous ceramics. International Journal of Mineral Processing, 93, 6-10. DOI: 10.1016/j.minpro.2009.04.007

Sapnjic, A., Stankovic, M., Majstorovic, J., Matovic, B., Ilic, S., Egelja, A. and Kokunesoski, M.: 2015, Porous ceramic monoliths on diatomite. Ceramics International, 41, 9245-9752.

Stamatakis, M.G., Fragoulis, D., Csirik, G., Bedelean, I. and Pederse, S.: 2003, The influence of biogenic microsilica-rich rocks on the properties of blended cements. Cement \& Concrete Composites, 25, 177-184.

Velho, J.L., Gomes, C. and Romariz, C.: 1998, MINERAIS INDUSTRIAIS Geologia, Propriedades, Tratamentos, Aplicações, Especificações, Produções e Mercados.

Xu, S., Wang, J., Ma, Q., Zhao, X. and Zhang, T.: 2014, Study on the lightweight hydraulic mortars designed by the use of diatomite as partial replacement of natural hydraulic lime and masonry waste as aggregate. Construction and Building Materials, 73, $33-40$.

Zbyszewski, G. and Matos, R.: 1959, Carta Geológica de Portugal, na escala de 1:50.000. Folha 26-D, (Caldas da Rainha). 